\title{
MIMICRY AND QUEST FOR IDENTITY: A STUDY OF ARVIND ADIGA'S THE WHITE TIGER
}

\author{
Subham Ghosh ${ }^{1}$ \\ ${ }^{1}$ Research Scholar, \\ Department of Humanities and Social Sciences, \\ IIT Patna, Patna, \\ India
}

Article DOI: https://doi.org/10.36713/epra5337

\begin{abstract}
In The White Tiger Arvind Adiga has portrayed a picture of India just after independence. Balram Halwai is the central character and this novel shows the struggle of Balram to make himself free from the "darkness", establishing as a successful entrepreneur and thereby making his Identity. Mimicry of the colonizers is a very common thing in a colonized nation but this paper, through the examples of the characters in the novel, will show how the subjects of a colonized nation continue to imitate others even after the colonial rulers are gone and how through this imitation they constantly recreate their identity and seeks to find an establishment.
\end{abstract}

KEY WORDS: mimicry, identity, postcolonialism, Arvind Adiga

\section{INTRODUCTION}

"...the rarest of animals, the creature that comes along only once in a generation" $(25)$ - this is how a white tiger is defined in Arvind Adiga's novel, and The White Tiger, the novel, is literally a "white tiger" in the "jungle" of Indian English literature, winning not only the Man Booker Prize in 2008 but also the hearts of the hundred million Indians at the same time. In this novel Adiga depicts a picture of post-independent India. The chaotic situation that prevailed in India just after the end of British rule is very much conspicuous here. He has come up with different themes like poverty, corruption, selfdetermination and life struggle in this novel but the charm of the novel is created by his artful juxtaposition and presentation of the opposite kind of things. On one hand he shows the poverty, malnutrition, illiteracy and "darkness" of the interior India and on the other hand he presents the India in light, the affluence and a promising market open for globalization. What happens when these two, radically different faces of India come face to face, interact with each other and eventually amalgamate is the very characteristics of the novel that mesmerizes us. Balram Halwai, the son of a rickshaw puller and born in a "dark" village named "Laxmangarh", is the central character of the novel. He could not continue his study and had to work to support his family, gradually climbed the ladder of the society only to become a successful entrepreneur at Bangalore; and his struggle in life and the experience that he gained makes up the basic skeleton of the narrative of the story. The whole story revolves around him, his poverty, how he came to the connection of rich people and finally became rich himself. However a second aspect that attracts our view is the development of characters. How the postcolonial people create their identity is a matter that needs to be put under microscope. People, in a newly independent India, take the recourse of mimicry and thereby recreate their identity in order to have a hold in the newly emerged society which is a fertile and promising ground for foreign trades and investment. Balram in this way becomes the famous Mr. Ashok of Bangalore from the poor boy of Laxmangarh. This paper therefore will try to investigate how the postcolonial theme of mimicry is adopted by the characters in The White Tiger and how, after becoming a "mimic man" they define their own self and identity.

\section{MIMICRY AND IDENTITY}

The term "mimicry" simply means "the imitation of one species by another" (Kumar 119). 
John R. G. Turner, in terms of bioscience defines "The resemblance of many organisms to some object is known as mimicry" (219). But in the domain of literature the term was made popular by the famous postcolonial critic Homi K Bhabha while analyzing colonized identity. He says, “...mimicry emerges as one of the most elusive and effective strategies of colonial power and knowledge." (126). The colonized are constantly taught that they don't have any past, any culture, any civilization; they are leading a barbarous life and therefore they are inferior to the colonizers. The colonizers defend their act of colonization by arguing that they, through the process of colonization, are performing their moral duty to make the uncivilized people civilized and educated. The colonized on the other hand out of an inferiority complex and an urge to rise up, tarts to ape the colonizers. They put on the colonizers' dress, practice their religion, behavior and eat their food. But ultimately there are certain things that cannot be imitated, such as the body complexion and therefore they end up becoming mimicry of the colonizers. This is what Bhabha defines "...a subject of a difference that is almost the same, but not quite" (126). Being mimicry the colonized suffer greatly from an identity crisis. They can neither relate themselves to their previous self nor are they accepted as equal to the colonizers. They constantly haunt for a stable identity that they can proclaim. And as they cannot find one, they start revolting against the rulers. However, this identity crisis continues even after the colonizers go away. Identity is the attribute that defines oneself and pinpoint one's position with respect to his surroundings. According to James Fearon, “...an identity is some distinguishing characteristic that a person takes a special pride in or views as socially consequential but more-or-less unchangeable." (2). But in a postcolonial nation the people suffer from the identity crisis even after the colonial rule comes to an end because the colonizers leave behind them the long drawn systems and bureaucratic policies that the colonizeds even after being free continues to practice. In such a postcolonial space one cannot hold his genuine self without mimicking others. As Lacan stated, "The effect of mimicry is camouflage.... It is not a question of harmonizing with the background, but against a mottled background, of becoming mottled..." (92). So, in the society the lower class people try to mimic and imitate the people belonging to higher class, to climb up the economic and social ladder of hierarchy. In The White Tiger, this is the same case where the poor people of India imitate the rich and the rich continue to imitate the so called "civilized" Europeans and Americans and in this process of mimicry their identity undergoes a huge change. Some can successfully establish themselves and create their desired identity; on the other hand there are some who in the quest of their identity doom their futures. This paper therefore will try to focus on some of the textual references from The White Tiger which will give us a clear picture of the postcolonial India and its people. It will try to investigate, through the character development of Balram and others, the effect of mimicry in their lives and their approach towards making of their new identity.

\section{BALRAM'S QUEST FOR IDENTITY}

The whole story of The White Tiger is written an epistolary form in which Balram writes to the Chinese Premier Mr. Wen Jiabao about his life and how he became one of the most successful entrepreneurs in Bangalore. Prashant Jadhav notes, "The identity is the prime concern in the novel through which the writer highlights most of the evils in the Indian societies" (36). Therefore the first ever description in the novel about Balram's early life is written thus: "He's half-baked.... That's the whole tragedy of this country" (Adiga 10). While introducing oneself one usually mentions the name first - the name with which he is identified. But for Balram, he didn't get even a name from his parents or grandparents: "I'd never been given a name" (Adiga 13), neither he had any idea of his age "...when I was six or seven or eight years old..." (Adiga 15). His first social identification, his name Balram, he got from the teacher when registering his name in the school. So we find the picture of a poverty ridden India where the people do not bother event to name their children. However Balram had something different in his mind: "I was destined not to stay a slave" (Adiga 41). It was his father who inspired him to be a true man with his own esteem and true identity. His father used to say, "My whole life, I have been treated like a donkey. All I want is that one son of mine - at least one - should live like a man" (Adiga 30). Balram had been a bright student in school. One day a school inspector came to visit the school and he was very impressed by the talent of Balram. He promised to arrange Balram a scholarship and from him Balram gets a new name, a new identity, "the white tiger". This name is very symbolic in this novel because Balram, unlike his father who had compared himself to donkey, in future will prove himself to be the rarest and fearless of all creatures - a white tiger in true sense. D. R. Paramita Roy comments upon this, "He kept his distinctiveness as the white tiger till the end of the novel, by being an individual with rare tenacity" (203).

Balram was taken out of school to work at a teashop and pay to his family, but his indomitable zeal to create his identity leads him to learn driving. Somehow he managed the money to pay the tutor but here was another problem. The caste and class based identity is very much prevalent in India. He was made to know that driving did not belong to the kind 
of job a "Halwai" did as his driving tutor commented, "It's like taming a wild stallion - only a boy from warrior caste can manage that.... Muslims, Rajputs, Shikhs - they're fighters, they can become drivers. You think sweet-makers can last long in fourth gear?" (Adiga 56). Not only the tutor, but his employers also were suspicious about his caste: "All our employees are top caste. I won't hurt to have one or two bottom castes working for us." (Adiga 64). Mandiclark observes upon this, "Balram Halwai's character serves as the primary representation of success in a simultaneously globalized and developing nation that still holds on to its precolonial class system...". Balram at this stage of development himself was not unbiased about caste and race. He was disgusted with the Nepali, Ram Prasad and his position as the second driver. He thought himself to be the most eligible for becoming the first driver. Kaharudin and Kurnia argues, "The Nepali is Nepali race. Ram Prasad is Arabian race, while Balram himself is Indian. He feels that he is the origin one, therefore, he indirectly desires to be the highest worker in the house" (100).

While writing about the voting system in India, the country which claims it to be the largest democracy, Balram angrily says, vote is a commodity in India, which can be sold and bought. When he worked in the tea shop at Dhanbad, once the tea-shop owner sold his and his co-workers' vote to a political party for some money. This is how one's right, one's identity is commodified here. He shares one of his father's experiences as' "My father told me that night, I've seen twelve elections - five general, five state, two local - and someone else voted for me twelve times" (Adiga 100). And regarding the present election he says political parties get their money from the rich men like the Stork who by donating some money to the party fund enjoys some illegal privileges. Therefore a citizen's identity for choosing their Government in India is really very illusive. However, coming to this point we have met almost all the characters and among them the characters of Balram, Vijay and Ashok are significant because they all had their ambition to do something moving out of the "darkness" and acquire not only a social status but an identity. In the words of Dr. Anjali Verma, "Adiga has graphically portrayed the different images of India - India of light and India of dark. But his focus is on the later and he tries to give it a literary voice." (04).

However the major thing that helped these characters to create their identity is the mimicry of others who are socially in a higher position, and in this novel the notion of mimicry is presented as an instinctive behavior of mankind as Balram, when at school tried to imitate the teacher's activity of chewing paan: "we stole paan from his pockets; distributed it amongst ourselves and chewed on it; and then' imitating his spitting style - hands on hips, back arched slightly - took turns spitting at the three dirty walls." (Adiga 29). As a child he was mesmerized to see Vijay, the bus conductor, with his shiny, meticulous uniform and silver whistle. And finally the grown up Balram, when visited Delhi, turned ambitious and again started to imitate the lifestyle of city people. He talked to the taxi drivers in Delhi and observed the attitudes of people. Famous postcolonial critic Derek Walcott comments, "To mimic one needs a mirror." (6), so for Balram, Ashok became the mirror looking at whom he could appropriate him. He started drinking whisky - though cheap in quality, buying t-shirts to look gorgeous and visiting prostitutes. He also stopped chewing paan; he started to brush his teeth and tried to keep himself reserved, rather than gossiping with other taxi drivers. But as Prof. Shakate Samarao observes, "Rootlessness is slowly developed in the mind of Balram. Cleaned society needs clean clothes but they need not clean men. Balram changed roles as per demand of the period..." (01), and his ambition for living the life of a master not of a slave grows more and more, which ultimately leads him to the murder of his own master, and finally at Bangalore he takes after the name of his master "Ashok" itself though the surname was Sharma. For Vijay, he also "changed uniform" again and again to climb up the ladder. From being the son of a pig farmer his first success came when he became a bus conductor which brought enough respect to him in the village but he was also very much ambitious and didn't stop merely becoming a conductor. He joined politics and it is due to his perfect mimicry and cunning wit that he moved forward rapidly in rank. At Delhi Balram again found him and became stunned to see the change he incorporated. He was wearing tie and shoes like a corporate man and was drinking foreign whisky with powerful politicians. Balram wondered how Vijay, his childhood hero had completely changed his identity and this made his ambition more deep rooted than before. And finally, in case of Ashok, he was also the son of the same soil where Balram was born and brought up but being the son of a rich landlord he was sent to America for study where he adopted himself in American culture. Due to his fascination to American culture he had married Pinky madam, a Christian and coming to India he took an Americanized apartment in Gurgaon. He had to go against the decision of his conservative and orthodox family of not marrying a non-Hindu woman. He also enjoyed foreign whisky and the suitcase that he used to carry for the bribes was also decorated in Italian style. Not only Ashok imitated the American lifestyle but also exoticised India before his wife. Under the influence of American culture he had also turned into a mimic man and this got clearly reflected by his movements and behaviors in the novel. 


\section{CONCLUSION}

So, coming to the conclusion, we can justifiably say that the characters, especially Balram, through constantly destroying their previous identity and mimicking the activities of others in better position, gradually reach a position of social establishment. Pinky retreats back to New York, at her space, to find her identity. The quest that Balram did his whole life may not have purified his soul morally but as ram Bhawan Yadav has noticed, "Adiga has commissioned a novel in which representation of subaltern and their resistance for their identity and status is presented as their struggle aspiring to be from periphery to entre" (3). Balram here represents the majority of Indian population who are poor and who live in the "darkness" and cannot define their identity. Balram is an inspiration for them who want to break the shackle and go out to recreate their identity, because in the very character of Balram the spirit of new India lies hidden as Kaharudin and Kurnia mentioned in their article, "Adiga's The White Tiger must be so close to this anticolonialism where Balram tries to be himself, not as slave, not as driver, but an entrepreneur. He seems to give an instance that India should be like him, free and no demands." (98).

\section{REFERENCES}

1. Adiga, Arvind. The White Tiger. New Delhi: Harper Collins Publishers, 2018. Print.

2. Bhabha, Homi K. "Of Mimicry and Man: The Ambivalence of Colonial Discourse." Discipleship: A Special Issue on Psychoanalysis 28.10 (1984): 125-133. JSTOR. Print

3. Fearon, James D. "What is Identity (as we now use the word)." Unpublished Manuscript. Stanford University, Stanford, Calif (1999).

4. Jadhav, Prashant. "Arvind Adiga's The White Tiger: A Search for Identity." New Man International Journal of Multidisciplinary Studies $1.4 \quad$ (2014): $36-41$. newmanpublication.com. Web. 17 Aug. 2020.

5. Kaharudin, Irawan, Fabiola D. Kurnia. "Postcolonialism as Spatial Politics in Arvind Adiga's The White Tiger." Litera-Kultura 3.1 (2015): 96-102. jurnalmahasiswa.unesa.ac.id. Web. 16 Aug. 2020.

6. Kumar, Sanjiv. "Bhabha's Notion of Mimicry and Ambivalence in V.S. Naipaul's A Bend in the River." Researcher's World - Journal of Arts, Science and Commerce 2.4 (2011): 118-122. Print.

7. Lacan, Jacques. The Four Fundamental Concepts of Psychoanalysis. Trans. Alen Sheridan. New York: W. W. Norton \& Company, 1981. Print.

8. Mandyclark. "The White Tiger, Arvind Adiga." Web blog post. Postcolonial Literature. Mandyclark, 5 Dec. 2012. Web. 17 Aug. 2020.

9. Roy, D. R. Pratima. "Issues of Identity in Arvind Adiga's The White Tiger and Fyodor Dostoevsky's Crime and Punishment."
International Journal of English Language, Literature and Translation Studies 2.1 (2015): 202-206. Print.

10. Samarao, Shakate Bharat. "The White Tiger: Quest of Existence." International Journal of Scientific and Research Publication 2.6 (2012): 1-2. ijspr.org. Web. 17 Aug. 2020.

11. Turner, John R. G. "Mimicry: A Study in Behavior, Genetics, Ecology and Biochemistry." Science Progress 58.230 (1970): 219-227. Print.

12. Verma, Anjali. "The White Tiger: A Postcolonial Perspective." Journal of Teaching and Research in English Literature 9.2 (2018): 1-4. sites.google.com. Web. 16Aug. 2020.

13. Walcott, Derek. "The Caribbean: Culture or Mimicry." Journal of International Studies and World Affairs 16.1 (1974): 3-13. Print. 